\title{
Use of Train Transport to Bridge Social-Economic Activities Between Indonesia and Timor Leste Along the Northern Coast of the Island of Timor: A Preliminary Study
}

\author{
Don Gaspar Noesaku da Costa ${ }^{1 *}$, Robertus Mas Rayawulan ${ }^{1}$, Krisantos Ria Bela ${ }^{1}$, \\ Mauritius I.R. Naikofi ${ }^{1}$, Engelbertha N. Bria Seran ${ }^{1}$, Rani Hendrikus ${ }^{1}$ \\ ${ }^{1}$ Study Program of Civil Engineering, Universitas Katolik Widya Mandira, Kupang, Indonesia \\ *Corresponding author. Email: dnoesaku@gmail.com

\begin{abstract}
Trading, agriculture, transportation and communication as well as services sectors are the prime contributors of the regional gross of domestic product in the island of Timor. However, the increasing of such priority sectors was relatively constant which might be occurred due to inappropriate efforts in integrating the transportation infrastructure and potential social-economic activities intra and/or inner districts. This paper focusing on how to increase such regional social-economic structure by developing better transportation services system which is assumed could attract tourism traveling number, i.e. based on integration between railways transportation system and local natural resources and/or social-economic activities. The indication of technical, economic, social and environmental as well as institutional arrangement feasibility then was analyzed using SWOT model. It was strongly indicated that the development of transportation network services based on railways network could trigger the augmentation of not only tourism trips but also the type, number, scale and spatial distribution of social-economic activities along the Northern coast of the island of Timor, as well as the regional gross of domestic product of both countries
\end{abstract}

Keywords-functional connectivity, social-economic activities, Timor Island, tourism train transport, transport land use

\section{INTRODUCTION}

Economic burden issues in isolated areas such as a number of villages in the Northern coast of the island of Timor as well as in Oecusse district (Timor-Leste enclave in Indonesia territory) due to limited of accessibility and population mobility is one of the main issue. Particular substance in Oecusse arose mostly since East Timor has been separated governmentally from Indonesia. This unlucky situation occurred because Oecusse was surrounded exclusively by the Indonesian administrative territory [1]. On the other hand, population trips between West Timor (Kupang - Atambua) and East Timor (Oecusse and Dilli) was primary rely on land transport using private and rent vehicles, dominantly by using passenger car, 24 seat of buses, minivan travel vehicles or even by using motorcycles. It took approximately 6-7 hours from Kupang to Atambua (around $300 \mathrm{~km}$ distance) and around 5-6 additional hours to reach Dilli due to topographical and geographical constraint.

Understandably, such poor transportation services might end up limited social and/or economical trips among them. Therefore, it is thought that a new social-economic trips might be proposed based on tourism activities because, visually, the Northern Coast line along West and East Timor offering a number of exotic and unique pleasure based on a combination between maritime, tropical landscape and hills viewing as can be seen in Figure 1, as well various traditional cultural attraction and local delicious culinary which are usually most considered by tourists. In this particularly case, it is thought that a railways services might be bridge such social-economic needs among East and West Timor. By constructing a new transportation services based on railways along such coast line, the social-economic trips could be increased significantly because it offers not only safer trip, shorter travel time, exact departure and arrival time, but mostly a remarkable recreational trips.

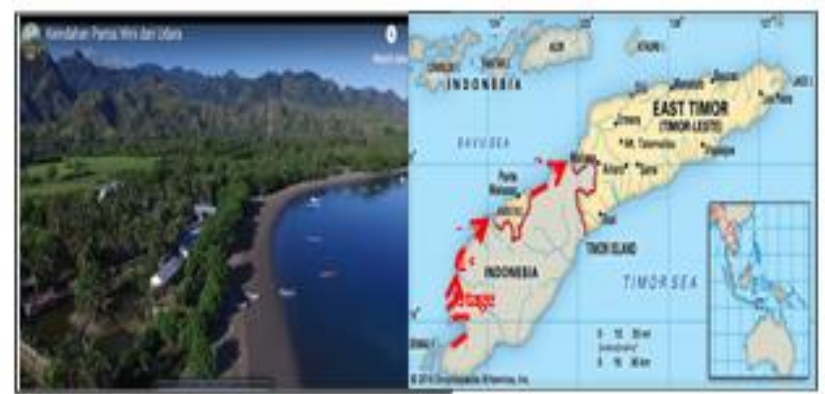

Fig. 1 Exotic view at Wini (left), and predicted route along the Northern Coast of the Island of Timor (red line, right) 
Use of specific rail road using particular train to be a recreational transport means in exotic and/or historical areas is not new idea because it has been built and operated in Alaska (White Pass \& Yukon Route), Swiss (Landwasser Viaduct), USA (Georgetown Loop Railroad), etc. Further, strategic and fundamental relationship between transportation, land use, and transport facility as well as transport means has been commonly known to be factors associated with social-economic and environmental structure as well as institutional arrangement performance. However, functional connectivity still a latent issue in Indonesia, Timor-Leste and other developing countries.

Considering the historical of socio-economic emotional ties and diversity of social-economic between East and West Timor societies [1], it is thought that an integrated land use and transportation services should be built because the new transport infrastructure such as airport and seaport built in Oecusse might give huge impact in social-economic improvement if they are connected with other transport infrastructure among the two sides, i.e. East and West Timor proportionally. It is an important consideration as functional connectivity between the two sides could give greater cumulative impact in social-economic development rather than if it relies on physical connectivity only. That is why it is though that tourism activities and trips based on train railways along the Northern Coast line of the island of Timor is a strategic opportunity that might be used to bridge such social-economic needs between the two countries as an ongoing basis.

Noteworthy that recreational needs for modern societies was triggered by their psychological and physical stress during working days and other routine activities [2]. This should be well response to be an opportunity to develop new sensational tourism object and/or activities, particularly in un-growth places which could offer their novel natural and/or cultural attractive objects. However, local people and even government officer usually give negative response (underestimate) about their potential natural and/or cultural resources. Therefore, it is required huge and continuing intervention in many aspects to promote, realize and develop these conceptual ideas. This study focuses on initial data collecting which might be used to propose a new land transport mode in island of Timor based on railways, including how to empower local people in accepting, and supporting the construction, usage and maintenance stages of such new infrastructure with its derivative of social-economic activity proportionally.

\section{STUDY DESIGN}

This is just a preliminary study intended to explore whether a railways route along the Northern coast of the island of Timor could increase social-economic structure or not. Hence, a desk study was undertaken focused on identification of determinant factors that might influence the development of transport infrastructure such as: 1) current social-economic characteristics (culture, perception, attitude, type and/or number of activities, scale of activities, distribution location of activities) 2) current transportation system (trip pattern, road network condition, pavement and geometrical conditions, trip generation and/or attraction (origin and destination trip), commuter and/or favorite route (trip distribution), primary transport means, etc.) 3) potential tourism objects and/or locations near by the Northern coast of the island of Timor 4) current type of institutional arrangement which responsibility in transportation system development. Therefore, an integration model between transport and land used was used to identify and/or analysis such intentions.

Further, as this substance of this paper is just a conceptual idea then all of the data and/or information are gathered from literature review (secondary data). Subsequently, the data then was analyzed using SWOT matrix so that some strategic recommendations could be produced proportionally.

This study focuses on how to generate tourism and population trip as well based on tourism activities and/or location development so that the analysis used rely on:

a. Natural and cultural tourism based management: which describe not only the type, number and scale and location distribution of current tourism activities but also the high potential tourism activities unique which could be promoted and/or developed. In this particularly case, the proposal of railways route and its potential stopping destination stretching from Kupang (West Timor) to Dilli (East Timor) through the Northern Coast line of the island of Timor would be determined based on such information.

b. Physical and functional connectivity which describe: 1) current physical and functional interconnecting (accessibility and mobility) as well as potential type of tourism activities that could be developed along the current transportation routes (trade follow the ship) 2) possibility in transport infrastructure network development that might support and/or connect the tourism trips to varying potential tourism location (ship follow the trade).

\section{RESULT AND DISCUSSION}

\subsection{Integration of land-use and transportation strategy}

From the result of initial observation, it was found that: 1) social-economic activity in Oecusse (Timor-Leste) and Wini (West Timor) has been connected with land transport using bus, minivan and motorcycles 3) primary local socialeconomic activities were based on agriculture, trade and fishery. 4) Airport intended to increase social-economic trips from/to Oecusse has been constructed and operated.

Figure 2 shows the conceptual framework needed to increase not only physical but also functional connectivity. In this particularly case, although transportation network has been well-known to be the primary factor associated with spatial development, but physical and functional connectivity in the island of Timor still could be a latent issues if:

a. Not every current land use has been sufficiently served by existing road-network which is indicated from the lack of road pavement condition and/or long distance travel time. 
The arterial road network is in good enough condition, but the current road network performance, particularly those in local and/or collector road network category, are difficult to be managed appropriately due to topography, as well as budget availability and/or inadequate of management capability (institutional arrangement constraints). In turn, such undesired situation might end up the lower growth in regional economic structured. In this particularly case, although there is an exotic view along the Northern Coast line stretching from Kupang City to Oecusse but it cannot be accessed easily.

b. A number of social-economic areas has not been physically connected. Even, although they were connected but there is limited trips due to lack in promotion and /or tourism supporting facilities (accommodation).In addition, there is no regular transport means to deliver visitor. Hence, the potential local tourism object and road network should to be identified and mapped so that public transport means, station and other supporting facilities could be planned and built systematically.

c. There is no alternative of traffic attraction or magnetism

Current conventional public transport was intended to serve regional trips which bringing both people and goods. It took long travel time and become uncomfortable. Therefore, the tendency to use the private rent car increase significantly. However, in order to achieve high daily income they usually speeding which could lead them to be involve in accident.

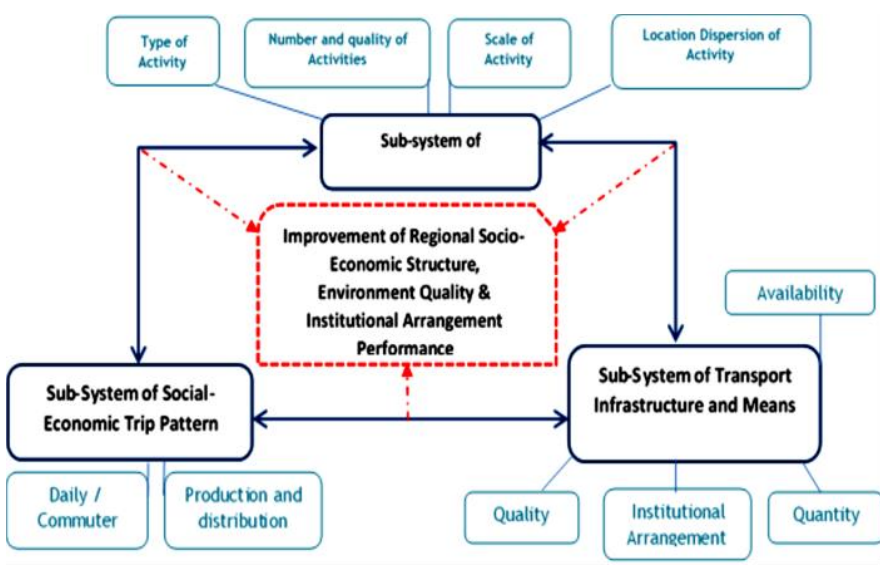

Fig.2. End up of Transportation System's Component Interaction [3].

That is why in order to increase social-economic trips, it is needed to develop other transport means whish offering better and/or greater social-economic advantages. Therefore, by considering the exotic view and/or experience that might be obtained during traveling along the coast, it is thought that use of the train transport might attract not only tourism but also regular or current social-economic trips. As previously mentioned, use of train as tourism transport means has been proved successfully operated in other countries [4].

The question is how to increase the bearing capacity based on integration between land use (tourism) and transport infrastructure? Such needs might be achieved through the following steps: 1) identification current accessibility and mobility pattern 2) identification and mapping of the potential social-economic resources and/or activities, including the trip distribution pattern as well as the type, number, scale and dispersion of location of such potential social-economic resources and/or activities 3 ) considering the production and distribution capability 4) providing supporting system and/or facilities.

\subsection{Accessibility and mobility issue}

\subsubsection{Current primary transport means and network}

If using land transportation, it is needed around 6-7 hours to travel from Kupang to Atambua and around 5-6 additional time to achieve Dilli. Such long distance traveling usually affect passenger health and comfortable significantly because the current route has been built associated with hilly and labyrinth topography. In addition, such travelling usually brought not only human but also goods and/or animal as well.

On the other hand, although there were ports at Wini, Atapupu and Oecusse, but they only servicing goods and animal transport. However, since all of them were placed at the northern coast of the island, it is thought that they might be developed to be public ports as well. This potential development is supported by the present of Oecusse airport recently launched. Accordingly, the development of train transport may not only offering better accessibility and mobility but also much other technical and social-economic as well as environmental advantages, such as: greater capacity, faster, safer, more energy saving, low emission and need less land / space [5]. Further, such potential benefits might be multiplied if it is used not only for domestic transport means but especially for tourism transport means. Use of the train itself has been proved to be the trip attraction factor for tourism activities [4], so that the exotic view and potential remarkable experience offered due to the present of savannah hills, rivers, beach and socio-cultural activities along the Northern coast of the island of Timor might be used to be the triggering factor of tourism trips.

\subsubsection{Physical and functional connectivity}

Thus far, current social-economic activities and/or trips has not been improved. It might be caused by the following situation: 1) lack of road pavement condition, particularly at Local Street, was the primary factor that caused less mobility inner and/or inter district, and 2) inadequate integration between transport and land use affect minor social-economic activities and/or trips. Therefore, it is required tactical effort by developing new social-economic activity center such as local culinary or traditional culture expo, or constructing representative infrastructure at potential natural tourism spaces, which is supported by the present of good transport means and network as well.

\subsection{Social-economic structure and variables that influence it}

\subsubsection{Prime contributors of regional gross domestic product}

In the Indonesian Master plan in Economic Acceleration and Extension Development year 2011-2025 (MP3EI) 
agenda, Bali and Nusa Tenggara (East and West Nusa Tenggara, including island of Timor) has been classified into the same economic corridor based on tourism and fishery sectors [6]. Recently, after Komodo has become one of the 7 wonder tourism object, a huge increasing in tourism activities occurred in the island of Flores. However, most of tourists only spent their valuable time in the island of Flores because there is no adequate information about the other potential tourism destination in East Nusa Tenggara, including in the island of Timor. This is an irony because Kupang City, the capital city of East Nusa Tenggara Province is located in West Timor, where is with its international airport status, it has been used as primary transit route of flight from Denpasar, Surabaya, Yogyakarta and other famous tourism places in Indonesia. That is why, developing new trips from/to Kupang - Oecusse due to the opening of new airport in Oecusse need to be further investigated. In addition, according to the center of statistical bureau of East Nusa Tenggara Province 2010-2017 it was found that agriculture and services were the most strategic factors that contribute significantly to domestic product of regional gross of East Nusa Tenggara Province, i.e. above $20 \%$ per year averagely. It shows that tourism, particularly based on maritime and/or cultural tourism has not been considered properly.

\subsubsection{Considering tourism trip productivity based on potential activities which could be developed}

Indicator used to ensure that developing of railways infrastructure, i.e. that such new infrastructure could support the increasing of regional income with minimal effect to current activities surround. Therefore, potential activities that might be developed are:

a. Traditional culinary tourism

b. Cultural attraction (folk song, dance and daily activities as well as handicraft souvenir)

c. Natural object viewing based on maritime (coast), rivers, savannah and hills object.

The development of new tourism destination center could trigger social-economic interaction possibility not only between East and West Timor people but also between them and tourists. Therefore, it is required to increase the institutional arrangement capability in not only financial establishment but also development of type, number, scale and dispersion of potential social-economic activities location continuously

\subsection{Strategic and Operational Planning}

The concerned strategies needed shown in Table 1 strongly indicate that a multi dimensions approaches are needed to be developed to accommodate and/or mitigate negative potential impacts.
Table 1. Matrix of SWOT analysis

\begin{tabular}{|c|c|c|}
\hline $\begin{array}{r}\text { Internal } \\
\text { Factor }\end{array}$ & 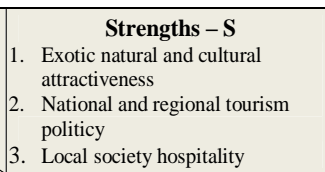 & 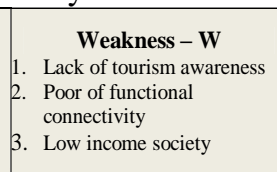 \\
\hline $\begin{array}{l}\text { Opportunities - O } \\
\text { 1. International recreational } \\
\text { demand } \\
\text { 2. Regional tourism trips } \\
\text { [transit route] }\end{array}$ & $\begin{array}{l}\text { SO-Strategies } \\
\text { 1. New alternative transport mode } \\
\text { and network } \\
\text { 2. Wonderful Nature, Culture, } \\
\text { People, Culinary and Price slogan } \\
\text { of promotion } \\
\text { 3. Tourism board establishment }\end{array}$ & $\begin{array}{l}\text { WO-Strategies } \\
\text { 1. Integrated land use and } \\
\text { transport system }\end{array}$ \\
\hline $\begin{array}{l}\text { Threats - T } \\
\text { 1. High construction cost } \\
\text { due to topographical } \\
\text { condition (hills, rivers) } \\
\text { 2. Land acquisition }\end{array}$ & $\begin{array}{l}\quad \text { ST }- \text { Strategies } \\
\text { 1. Loan and/or foreign investment } \\
\text { support } \\
\text { 2. Use of traditional (elderly culture } \\
\text { authorities) and church power in } \\
\text { financial political bargaining }\end{array}$ & $\begin{array}{l}\text { WT - Strategies } \\
\text { 1. Diffusion of innovation } \\
\text { 2. Long life investment scale } \\
\text { for impacted people based } \\
\text { on compensation fund } \\
\text { "sirih-pinang", work and } \\
\text { available space for social- } \\
\text { economic activities around } \\
\text { tran station including } \\
\text { parking retribution } \\
\text { management access }\end{array}$ \\
\hline
\end{tabular}

\subsection{Considering the capability of railways infrastructure development and its operational network scheme}

\subsubsection{Technical aspects}

Lesson learned from other countries strongly indicate that topography, geological and seismic, construction material, building capability, construction maintenance and durability constraints could be not only being managed but also used to be the attractiveness factor. For example:

1) Considering of the artistic type of rail construction suited to local geological, topography and seismic conditions because the island of Timor was categorised in high risk of seismic, and there are a lot of river as well as hills. However, the local river stone could be used to be ballast construction suited to physical and mechanical criteria or condition restricted by Transportation Ministry regulation [7]. The location of quarry and/or stone crusher could be placed anywhere.

2) PT Kereta Api Indonesia (Indonesian Train Association) has been proved their capability in construct, operate and maintain railways system significantly [8]. Train transport not only offering cheaper travel cost but also better reliability and comfortable trips.

3) Regular shelter might be built along the track route so that passenger have a lot of option or opportunity to stop and visit various attractive cultural activities and/or local culinary zone offered surround it. In addition, specific optional route (closed circuit track) in exotic areas around the shelter, with additional cost of course, could be used to increase tourism trip attraction. This could increase tourism and domestic trips. Politically, tourism is an international opportunity so that appropriate policy and sustain financial support should be arrange comprehensively because a change in travel styles itself could attract social-economic trips [9]. On the other hand, the present of such train transport should support current local public, in accord with Ansusanto and Pramarito (2010), by developing multimode station in each shelter. 
The implication is such management strategy require these following supporting efforts:

a. Local cultural arrangement is needed to ensure that local citizen could be part of such changes. It has to be suited with local perspectives, behaviour, needs, and aspiration. Accordingly, suitable social communication model should be developed. Besides, management of the effect of land use change due to railways system infrastructure should be focused on how to optimize local agriculture, arts and their potential cultural product into tourism services product by using diffusion of innovation model.

b. The following political bargaining approach strategy might be considered because previous public infrastructure construction is usually related to land acquisition and/or compensation:

1) Compensation incentive might be combined with work access and/or potential public space organizing, such as parking retribution management, for direct impacted citizen. It should be their long life investment scale form.

2) Relying on natural and cultural tourism trips based on consumer satisfaction values so that their journey could be remembered as a remarkable trip

3) Staggered construction (route) and operational activities based on location of the potential shelter and/or tourism activities centre identified and/or mapped. In this case, policies considered to reduce the burden of the cost of construction and the government guarantee for the risk might contributed in financial feasibility [11]

\section{CONCLUSION}

Based on the research, there are four conclusions that can be drawn.

1. Current problems of transportation system in the island of Timor are related to the following matter: 1) functional dis-connectivity 2) lack of infrastructure funding 3 ) poor transport infrastructure and land use planning.

2. Technically, the construction of a railways network intended to increase both the physical and functional connectivity between West and East Timor through the Northern coastline of the island of Timor could be built. In addition, the development of a number of potential tourism destinations along the coastline enables ongoing interaction between the people of Timor-Leste and
Indonesia, which in turn is expected to strengthen not only the socio-economic and political ties but also socialeconomic structure between the two countries.

3. Crucial issues related to train route development possibility and priority tourism destination spot along the route are ongoing operational and maintenance capacity and how to manage a better diffusion of innovative.

4. Development of integrated transportation infrastructure might minimize the socio-economic gaps and burdens issues properly.

\section{REFERENCES}

[1] Globalism Institute, "Pembangunan Sosial dan Ekonomi di Oecusse , Timor-Leste," 2008.

[2] I. B. G. Pujaastawa, Diktat antropologi pariwisata. Denpasar: Universitas Udayana, 2017.

[3] D. G. N. da Costa, "Aplikasi Pendekatan Kesisteman dalam Pengembangan Konsep Strategi Implementasi Program MP3EI di NTT," Mayarakat Transp. Indones., vol. 1, no. 1, pp. 1-17, 2016.

[4] D. Michniak, "Role of Railway Transport in Tourism: Sellected Problems and Examples in Slovakia," vol. 35, no. 4, 2016.

[5] Kementrian Perhubungan, "Rencana Induk Perkerataapian Nasional, Ditjen Perkeretaapian, Jakarta," 2011.

[6] Pemerintah Republik Indonesia, "Peraturan Presiden Republik Indonesia Nomor 32 Tahun 2012 tentang Masterplan Percepatan dan Perluasan Pembangunan Ekonomi Indonesia 2011-2025,” 2011.

[7] Kementrian Perhubungan, "Peraturan Menteri Perhubungan Nomor: 60 Tahun 2012 tentang Persyaratan Teknis Jalur Kereta Api,” 2012.

[8] D. E. Pramyastiwi, I. Hardijanto, and A. Said, "Perkembangan Kualitas Pelayanan Perkeretaapian sebagai Angkutan Publik dalam Rnagka Mewujudkan Transportasi Berkelanjutan," J. Adm., vol. 1, no. 3, pp. 61-69, 2013.

[9] H. Saimyo, "Relationships between Railways and Tourism," 2010.

[10] J. D. Ansusanto and A. A. Pramarito, "Persaingan Moda Transportasi Darat Jarak Pendek (Kereta Api Komuter dengan Bus Ekonomi)," in Konferensi Nasional Teknik Sipil-4, 2010, vol. 4, no. KoNTekS 4, p. I-413-418.

[11] Herman, "Kajian awal kelayakan finansial investasi jalan rel," in The 18th FSTPT International Symposium for Indonesia Transport Studies Studies Forum, 2015, pp. 1-12. 